\title{
Defective Uteroplacental Vascular Remodeling in Preeclampsia: Key Molecular Factors Leading to Long Term Cardiovascular Disease
}

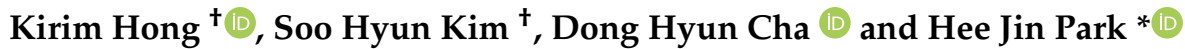 \\ Department of Obstetrics and Gynecology, CHA Gangnam Medical Center, CHA University, Seoul 06125, Korea; \\ rachelkh@chamc.co.kr (K.H.); soohyunkim@chamc.co.kr (S.H.K.); chadh001@chamc.co.kr (D.H.C.) \\ * Correspondence: coolsome72@chamc.co.kr \\ + Equally contributed as first authors.
}

check for

updates

Citation: Hong, K.; Kim, S.H.; Cha, D.H.; Park, H.J. Defective

Uteroplacental Vascular Remodeling in Preeclampsia: Key Molecular Factors Leading to Long Term Cardiovascular Disease. Int. J. Mol. Sci. 2021, 22, 11202. https:// doi.org/10.3390/ijms222011202

Academic Editors: David K. Stevenson and Nihar Ranjan Nayak

Received: 8 September 2021

Accepted: 16 October 2021

Published: 18 October 2021

Publisher's Note: MDPI stays neutral with regard to jurisdictional claims in published maps and institutional affiliations.

Copyright: (c) 2021 by the authors. Licensee MDPI, Basel, Switzerland. This article is an open access article distributed under the terms and conditions of the Creative Commons Attribution (CC BY) license (https:// creativecommons.org/licenses/by/ $4.0 /)$

\begin{abstract}
Preeclampsia is a complex hypertensive disorder in pregnancy which can be lethal and is responsible for more than 70,000 maternal deaths worldwide every year. Besides the higher risk of unfavorable obstetric outcomes in women with preeclampsia, another crucial aspect that needs to be considered is the association between preeclampsia and the postpartum cardiovascular health of the mother. Currently, preeclampsia is classified as one of the major risk factors of cardiovascular disease (CVD) in women, which doubles the risk of venous thromboembolic events, stroke, and ischemic heart disease. In order to comprehend the pathophysiology behind the linkage between preeclampsia and the development of postpartum CVD, a thorough understanding of the abnormal uteroplacental vascular remodeling in preeclampsia is essential. Therefore, this review aims to summarize the current knowledge of the defective process of spiral artery remodeling in preeclampsia and how the resulting placental damage leads to excessive angiogenic imbalance and systemic inflammation in long term CVD. Key molecular factors in the pathway-including novel findings of microRNAs-will be discussed with suggestions of future management strategies of preventing CVD in women with a history of preeclampsia.
\end{abstract}

Keywords: preeclampsia; spiral artery remodeling; cardiovascular disease

\section{Introduction}

Preeclampsia is a subtype of hypertensive disorders of pregnancy (HDP), defined as hypertension (systolic blood pressure $\geq 140 \mathrm{mmHg}$ and/or diastolic blood pressure $\geq 90 \mathrm{mmHg}$ ) newly developed at or after 20 weeks of pregnancy with at least one of following conditions: proteinuria ( $\geq 1+$ dipstick; $\geq 30 \mathrm{mg} / \mathrm{mmol}$ protein:creatinine ratio; or $\geq 300 \mathrm{mg} / 24 \mathrm{~h}$ ), maternal organ dysfunction (hepatic, renal, hematological, or neurological conditions), or uteroplacental dysfunction (such as abnormal umbilical artery Doppler wave form analysis, fetal growth restriction, or stillbirth) [1]. The incidence of preeclampsia is reported to be $5-7 \%$ of all pregnancies, which can cause fatal conditions in the mother and the newborn [2].

Besides the higher risk of unfavorable obstetric outcomes in women with preeclampsia, another crucial aspect that needs to be considered is the association between preeclampsia and the postpartum cardiovascular health of the mother. According to the American Heart Association, preeclampsia is classified as one of major risk factors of cardiovascular disease (CVD) in women [3]. In fact, according to a large scaled meta-analysis, a history of preeclampsia doubles the risk for subsequent venous thromboembolic events, stroke, and ischemic heart disease over five to 15 years postpartum in women [4]. While some of the maternal systemic damage by preeclampsia returns to normal after delivery, it has become apparent that the vascular dysfunction by several molecular factors persists beyond the acute disease in pregnancy. Therefore, in order to comprehend the pathophysiology behind 
the linkage between preeclampsia and postpartum CVD, a thorough understanding of the abnormal uteroplacental vascular remodeling is essential.

\section{Uteroplacental Vascular Development in Normal Pregnancy}

The development of placental vasculature begins from the beginning of pregnancy as the blastocyst implants into the decidua. The cytotrophoblasts which originate from the extra-embryonic membranes of the fertilized ovum mediate this process by differentiating into endothelial cells as they invade into the uterine wall to form primary capillaries of placental vasculature [5]. As the implanted embryo develops, trophoblast cells continue to branch into the inner third of the myometrium and reach the maternal spiral arteries at the intervillous space where maternal-placental circulation occurs. Uterine spiral arteries are nonbranching end arteries of uterine arteries which penetrate the inner part of the myometrium and the endometrium with a corkscrew shape [6]. During pregnancy, the spiral arteries are responsible for providing adequate perfusion of uteroplacental blood flow. Therefore, the spiral arteries are physiologically modified in order to change from high-resistance vessels to dilated low-resistance vessels with a thin wall [7]. The process of so-called "spiral artery remodeling" has been suggested to have five stages according to Pijenborg et al. [8]. Stage 1 involves the swelling of individual smooth muscle cell in the uterine spiral artery along with endothelial vacuolation. Stage 2 begins with interstitial trophoblasts invading the perivascular tissues and disorganizing the vascular smooth muscle layer. It is followed by the appearance of endovascular trophoblasts (stage 3 ) and the trophoblast becomes embedded into the vessel wall, becoming intramural trophoblasts in stage 4 . In stage 5, the re-endothelialization with newly built endothelium and the thickening of subintima containing myofibroblasts occur. During the process, several regulatory factors are involved; the high oxygen concentration in the spiral artery initiates the endovascular trophoblast invasion and activation of maternal decidual natural killer cells and platelets enhance their invasion [9]. Therefore, eventually the spiral arteries are physiologically altered to exhibit low vascular resistance and enhanced vasodilation, and this is specifically designed to provide sufficient uteroplacental circulation, which is critical for a successful pregnancy.

\section{Defective Uteroplacental Vascular Remodeling in Preeclampsia}

The association with failed spiral artery remodeling in development of preeclampsia was first brought up in 1972 by Brosens et al. [7]. Subsequent studies have revealed that due to a failure in the process of endovascular trophoblast invasions, spiral arteries fail to go through the physiological alteration process which results in relatively narrow, thick-walled and tortuous vessels in preeclampsia. Moreover, unlike in a normal pregnancy in which the transformation of the spiral artery extends from the decidual segment to one-third of the myometrial segment, in preeclampsia trophoblasts fail to invade into the myometrial segment of spiral arteries [10]. As a consequence, deep placentation fails and the blood flow to the placenta is restricted leading to inadequate uteroplacental perfusion. This phenomenon is found in various adverse pregnancy outcomes along with preeclampsia, such as fetal growth restriction, placental abruption, preterm labor, preterm premature rupture of membranes, and intrauterine fetal death [11-14].

\section{Two Step Model of Preeclampsia}

In order to understand how the defective spiral artery remodeling leads to preeclampsia, a thorough comprehension of the two step model is crucial. Preeclampsia manifests differently depending on the onset of the disease where the early onset form (develops before 34 weeks of gestation) is highly related to complications associated with placental dysfunction, such as a higher rate of fetal growth restriction, reduced placental volume, and low birth weight [15], while the late onset form of preeclampsia (develops at or after 34 weeks of gestation) is considered as a maternal syndrome without poor placentation, which rarely results in fetal growth restriction or low birth weight [16]. In fact, incomplete 
spiral artery remodeling is mostly seen in the early onset type of preeclampsia which serves as the 'extrinsic' cause of poor placentation. On the other hand, the late onset preeclampsia exhibits normal physiologically transformed spiral arteries with 'intrinsic' cause of placental malperfusion, caused by overcrowding of terminal villi as placental growth exceeds its functional limit. Overall, the abnormal intervillous blood flow results in ischemic-reperfusion injury and generates synciotrophoblast hypoxia stress [17]. Hence, although the pathways differ in their origin they both eventually lead to the maternal syndrome of preeclampsia resulting in high blood pressure and organ dysfunctions.

Therefore, the updated two-step model describes how the different two types of pathways lead to the development of clinically recognized preeclampsia [16]. As described in Figure 1, stage 1 represents the placental dysfunctional stage with syncytiotrophoblast stress which results either from extrinsic or intrinsic cause as described earlier. In order for the disease to manifest as clinical syndrome of preeclampsia (stage 2), inflammatory factors produced by syncytiotrophoblast stress in stage 1 activates the maternal endothelium resulting in generalized vascular inflammation and endothelial dysfunction leading to maternal clinical signs of hypertension and organ failure.

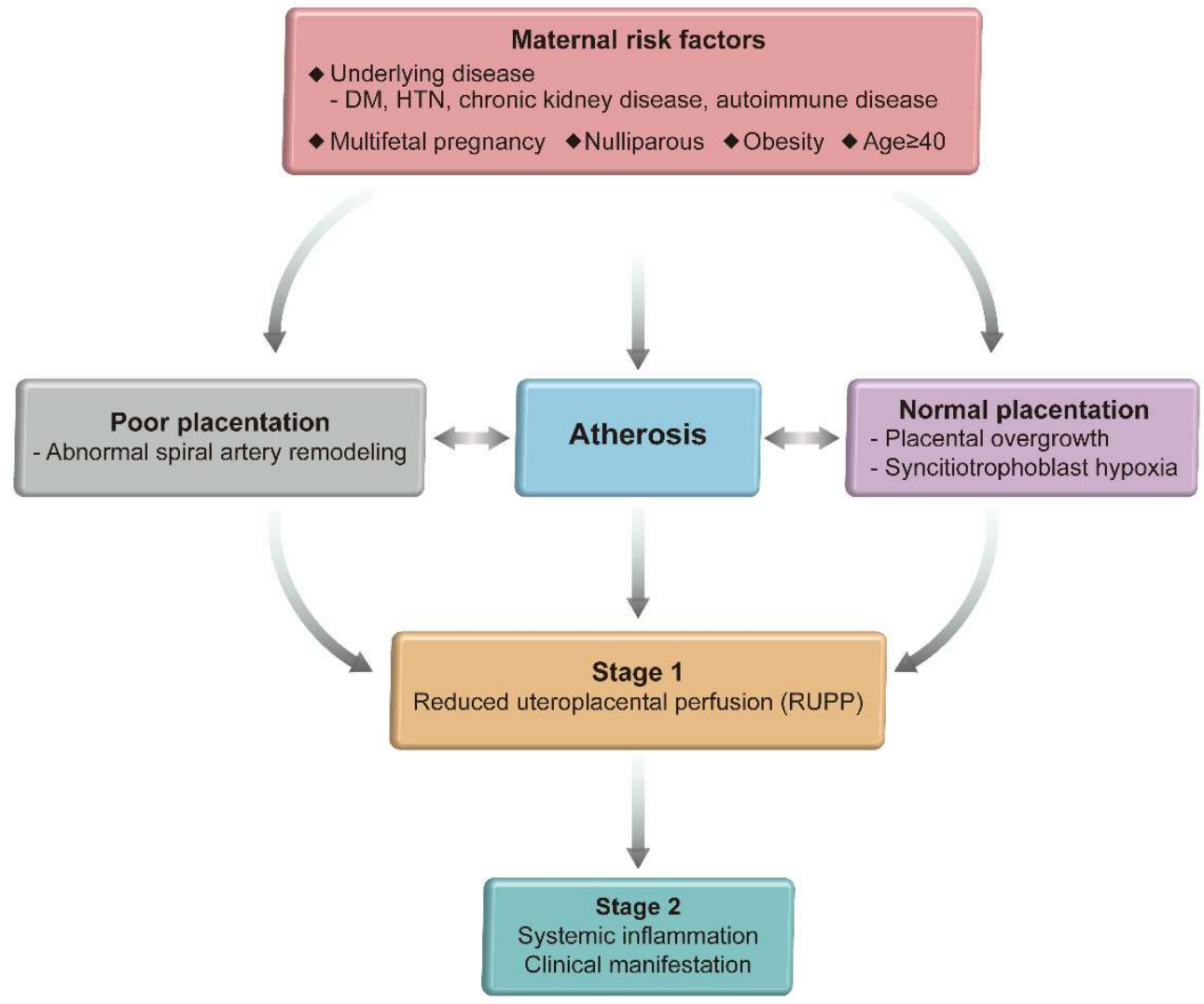

Figure 1. Two step model of preeclampsia.

\section{Atherosis}

Nevertheless, impaired spiral artery remodeling alone is insufficient to explain the diverse maternal clinical syndromic signs of preeclampsia and how it actually increases the risk of cardiovascular disease after the pregnancy. In women with preeclampsia, intravascular inflammation and dysfunctional lipid metabolism is commonly found, characterized by increased low-density lipoprotein and triglycerides, and decreased high-density lipoprotein $[18,19]$; these factors lead to lipid deposition in walls of spiral arteries which resemble early stages of atherosclerosis and the vascular lesions are named as 'atherosis'. Acute atherosis is characterized by the presence of subendothelial lipid-filled foam cells, perivascular lymphocytic infiltration and vascular fibrinoid necrosis, which result from 
inflammatory stress and arterial damage (Figure 2) [20]. These evidence of vascular inflammation are similarly found in transplant vasculopathy and atherosclerosis in patients with ischemic heart disease [21]. Once present in pregnancy, atherosis lesions can lead to placental dysfunction by narrowing the lumen of spiral arteries which leads to inadequate uteroplacental perfusion [22]. In fact, the prevalence of atherosis is higher in preeclampsia compared to normotensive pregnancies which has been reported as $10-52 \%$ and $0.4-11 \%$, respectively [23-26]. Therefore, atherosis in the maternal vascular system serves as a major risk factor for both early and late onset preeclampsia which eventually leads to stage 1 in the previously mentioned 2-stage model. Moreover, several molecular factors involved in placental dysfunction can also cause acute atherosis, which will be discussed in greater detail below [27].

\section{Molecular Factors Resulting from Inadequate Uteroplacental Perfusion Leading to Preeclampsia}

\subsection{Inflammatory Factors}

Placental ischemia due to reduced uteroplacental perfusion pressure (RUPP) increases the release of proinflammatory cytokines. TNF- $\alpha$ is increased in plasma of women with preeclampsia as compared to normal pregnant women [28], which increases vascular permeability and lymphocyte activation and disrupts mitochondrial function leading to oxidative stress [29].

Interleukin-6 (IL-6) is elevated in patients with preeclampsia compared to women with normal pregnancy [28]. IL-6 dislocates the tight junctions in endothelial cells which leads to increased vascular permeability and endothelial dysfunction [30]. This has been confirmed in rats with reduced uteroplacental perfusion which showed increased plasma levels of IL-6 with high CD4+ T cell production of inflammatory cytokines [31]. Also, chronic infusion of IL-6 in pregnant rats caused hypertension and proteinuria along with reduced vascular relaxation [32].

Interleukin-10 (IL-10) is an anti-inflammatory cytokine which is reduced in the placenta of rats with reduced uteroplacental perfusion and in serum of women with preeclampsia $[33,34]$. A recent meta-analysis of 56 studies on the circulating IL-10 levels in preeclamptic women revealed that the serum IL-10 levels were not significantly different before the onset of preeclampsia; however, once the clinical syndrome of preeclampsia occurs, IL-10 levels were significantly lower in preeclamptic women compared to normotensive controls (standardized mean differences, $-0.79[95 \% \mathrm{CI},-1.22$ to -0.35$] ; p=0.0004$ ). Moreover, the decreased level of IL-10 was present in all forms of preeclampsia regardless of its onset and severity [35]. This suggests that IL-10 levels may not be a suitable marker for early detection of preeclampsia, but increasing IL-10 may be a potential therapeutic target of preeclampsia, which could lead to future studies.

\subsection{Reactive Oxygen Species (ROS)}

Reactive Oxygen Species (ROS) such as superoxide, hydrogen peroxide, and the hydroxyl ion contains highly reactive oxygen. Pregnancy itself is a state of oxidative stress resulting from placental metabolism and increased maternal metabolic activity, which is counterbalanced by abundant antioxidants [36]. In preeclampsia, decreased expression of antioxidants such as heme oxygenase-1 (HO-1), HO-2, copper/zinc superoxide dismutase (SOD), glutathione peroxidase (GPx) and catalase fails to counterbalance the increased ROS production, leading to lipid peroxidation, increased thromboxane A2 and loss of GPx activity in the placenta [37]. The impaired blood flow in the spiral arteries due to RUPP also mediates an ischemia/hypoxia-reperfusion injury, leading to oxidative changes in placental proteins and lipids, mitochondrial injury, and increased ROS production [38]. In women with preeclampsia, decreased serum levels of the antioxidant ascorbate were shown to be associated with decreased brachial artery flow-mediated dilation, and administration of ascorbic acid improved flow mediated dilation, supporting an association between endothelial dysfunction and oxidative stress in preeclampsia [39]. 
Moreover, oxidative stress results in reduced bioavailability of nitric oxide (NO), a major vasodilator which regulates blood pressure in placenta [40]. Oxidative stress inhibits nitric oxide synthase (eNOS) which is required for biosynthesis of $\mathrm{NO}$, and the radical anion superoxide $\left(\mathrm{O}_{2}{ }^{--}\right)$reacts with $\mathrm{NO}$ to form peroxynitrite $\left(\mathrm{ONOO}^{-}\right)$, which is a strong pro-inflammatory factor [41].

\subsection{Angiotensin II (AngII) and Angiotensin II Type 1 Receptor (AT1R) Autoantibodies (AT1-AA)}

Angiotensin II (AngII) is an important regulator of blood pressure and electrolyte homeostasis. About $40 \%$ of AngII is produced locally in the placenta by chymase, a chymotrypsin-like serine protease, which is a non-angiotensin converting enzyme found mainly in the syncytiotrophoblast of the placenta. AngII via the AngII type 1 receptor (AT1R) promotes vasoconstriction, vascular growth, and inflammation, and increases intracellular free $\mathrm{Ca}^{2+}$ concentration and Rho/Rho-kinase activity in vascular smooth muscle. AngII via the endothelial angiotensin II type 2 receptor (AT2R) activates eNOS, and increases production of NO and prostacyclin (PGI2) which oppose AngII-induced vasoconstriction. Although increased plasma levels of renin and AngII is observed in normal pregnancy, the response to AngII is decreased due to decreased expression of AT1R, possibly by AT2R. However, hypoxia in RUPP has been shown to increase the AT1R expression and plasma levels of AngII in rabbits, as well as in human preeclamptic placentas [42,43].

In preeclampsia, AT1R forms a heterodimer with the bradykinin B2 receptor (B2R) called AT1R-B2R protein complex and becomes hyper-responsive to AngII; AT1R-B2R formation is increased in preeclampsia since down-regulation of the protein complex expression is inhibited due to beta-arrestin1 (ARRB1) dysfunction [44]. Therefore, AT1RB2R has become an emerging treatment target of preeclampsia. The beta-arrestin-biased AT1R agonist, TRV027, is expected to stimulate the AT1R-B2R downregulation-which is impaired in preeclampsia-and recent experiments have shown that it actually lowered blood pressure and prevented symptoms of preeclampsia in animal models [44,45].

AT1-AA are agonistic autoantibodies to the AT1R that mediates vascular signaling via protein-1, calcineurin, and nuclear factor kappa B (NFkB). AT1-AA induces the secretion of plasminogen activator inhibitor-1 (PAI-1) which inhibits trophoblast invasion, increases ROS, increases intracellular free $\mathrm{Ca}^{2+}$ concentration, activates the tissue factor causing thrombosis, and increases blood pressure [46]. Moreover, AT1-AA along with circulating cytokines stimulate endothelial cells to produce endothelin-1 (ET-1) in preeclampsia, which is a major endothelium-derived vasoconstrictor [47]. Infusion of CD4+ T cells obtained from preeclamptic women in pregnant rats stimulates the immunoglobulin release from B-cells which in turn increases AT1-AA production while inhibition of B-cells reduces AT1-AA mediated hypertension in these rats [48]. Therefore, AT1-AA serves as a possible therapeutic target for treating preeclampsia. Moreover, previous studies have shown that maternal AT1-AA persisted up to 27 months after pregnancy in $17.2 \%$ of women with preeclampsia compared to $2.9 \%$ in women with normotensive pregnancy [49]. Recently, a follow up study on circulating AT1-AA levels at five to eight years postpartum was published which showed that AT1-AA was persistently found in women with a history of preeclampsia, which might relate to their future CVD risk [50].

\subsection{Angiogenic/Antiangiogenic Factors}

Angiogenic factors are most highly expressed in early pregnancy and are responsible for placental angiogenesis and increasing placental mass that follows fetal growth [51]. Previous studies have revealed that RUPP leads to altered concentrations of pro- and antiangiogenic factors in women with preeclampsia, which leads to endothelial dysfunction and suggests that they are responsible for the pathology of maternal clinical manifestations of preeclampsia [52]. 


\subsubsection{Vascular Endothelial Growth Factors (VEGF)}

The VEGF family includes [VEGF-A, VEGF-B, VEGF-C, VEGF-D and placental growth factor (PlGF)], and their receptors [VEGFR-1/fms-like tyrosine kinase-1 (Flt-1), VEGFR$2 /$ kinase insert domain receptor (KDR), VEGFR-3/fms-like tyrosine kinase receptor-4(Flt4)]. Vascular endothelial growth factor (VEGF) is highly expressed in decidual cells and invading cytotrophoblasts in normal pregnancy, which leads to endothelial cell proliferation for newly developing capillaries in uteroplacental circulation [53]. Moreover, VEGF-A regulates trophoblast functions such as proliferation, differentiation, and invasion, mainly through the Flt-1 and KDR receptors [54]. In preeclampsia, the circulating level of VEGF is decreased and this has been confirmed in studies with RUPP-induced rats in which the VEGF level is also reduced [55,56].

\subsubsection{Placental Growth Factor (PlGF)}

Placental growth factor (PIGF), a member of the VEGF family, is another proangiogenic factor that binds to Flt- 1 which augments the angiogenic effect of VEGF. PlGF exerts not only direct effects on endothelial cells, but also indirect effects on nonvascular cells with pro-angiogenic activity by altering the functioning of immune cells; it recruits monocytes and activates macrophages which can release angiogenic factors, and encourages proliferation of mesenchymal fibroblasts and attracts myeloid progenitors to develop sprouts and collateral vessels [57]. Moreover, PlGF promotes vasodilation of uteroplacental circulation [36]. However, the circulating level of PIGF is decreased in preeclampsia compared to normal pregnancy, which leads to increased vascular resistance in preeclampsia [58]. Therefore, the National Institute for Health and Care Excellence guideline has recommended that obstetricians to utilize maternal serum PlGF levels to rule out preeclampsia in pregnant women with chronic hypertension or who are at a high risk of developing preeclampsia [59].

\subsubsection{Soluble FMS-Like Tyrosine Kinase I (sFlt-1)}

As a VEGF receptor, Flt-1 is highly expressed in the invading extravillous trophoblasts in the first trimester, which implies that VEGF-Flt-1 interactions lead to early trophoblast invasion [60]. As gestational age develops, VEGF-Flt-1 interaction also guides trophoblast differentiation and migration [61]. Soluble FMS-like tyrosine kinase I (sFlt-1) is a truncated protein resulting from splicing of Flt-1 which lacks the cytoplasmic and transmembrane domain but keeps the ligand-binding domain [62]. Therefore, sFlt-1 antagonizes and inhibits VEGF and PIGF by binding to them and blocking their interaction with Flt-1 for proangiogenic function. In preeclampsia, placental ischemia resulting from RUPP may stimulate upregulation of sFlt-1 by binding of hypoxia inducible factor (HIF) to the promotor of Flt-1 gene [55]. The elevated maternal serum level of sFlt-1 in preeclampsia has been found to be associated with severe endothelial dysfunction and inhibition of VEGF and PIGF by sFlt-1 serves a major pathogenic role in hypertension and proteinuria [5]. VEGF is responsible for decreasing vascular tone and blood pressure by inducing nitric oxide and prostacyclins that have a vasodilatory effect in endothelial cells, which is blocked by sFlt-1. In addition, several molecular mechanisms of sFlt-1 found to be responsible for renal dysfunction are related to glomerular capillary endotheliosis, dysregulation of the glomerular filtration apparatus, and podocyte loss [63]. Therefore, excess of sFlt-1 results in the characteristic antiangiogenic state of preeclampsia which manifests as the clinical syndrome of endothelial dysfunction. In fact, maternal serum level of sFlt-1 to PlGF ratio (sFlt-1/PlGF ratio) can be used as a reliable biomarker for predicting development and severity of preeclampsia [64]. Moreover, a recent systematic review and meta-analysis on the performance of the sFlt-1/PlGF ratio in predicting adverse outcomes in women diagnosed or suspected of preeclampsia showed that the sFlt-1/PIGF ratio performs better in predicting women with early onset preeclampsia in comparison to those with late onset [65]; this relates to our previous topic in chapter 4 which described that defective uteroplacental vascular remodeling is mostly seen in the early onset type of preeclampsia. 


\subsubsection{Soluble Endoglin (sEng)}

Soluble endoglin (sEng), a coreceptor for transforming growth factor- $\beta 1$ (TGF- $\beta 1$ ), is another antiangiogenic factor released by the placenta that acts in synergy with sFlt- 1 . Endoglin (Eng) is an angiogenic receptor expressed mainly on the surface of placental syncytiotrophoblast and endothelial cells which serves as a co-receptor of angiogenic TGF- $\beta$ signaling [66]. TGF- $\beta$ is known to contribute to angiogenesis and appropriate vascular relaxation by increasing VEGF $[67,68]$. However, in preeclampsia sEng is released in excessive quantity and binds to free TGF- $\beta 1$ which inhibits the pro-angiogenic TGF- $\beta 1$ signaling in the vasculature. The circulating level of sEng is elevated in patients with preeclampsia two-to-three months prior to the onset of clinical symptoms and its serum levels seem to be correlated with the severity of the disease [69].

\subsection{Activin A}

Activin A is a dimeric glycoprotein belonging to the TGF- $\beta$ family produced by the placenta and fetal membranes [70]. In preeclampsia, the serum level of activin A is elevated (up to 10-fold) compared to normal pregnancy and it is found to be resulting from increased placental production triggered by oxidative stress [71,72]. In fact, circulating levels of activin A have shown to rise months prior to the onset of the clinical manifestation of preeclampsia, which is earlier than the elevation of sFlt-1 or sEng [73]. Recent studies have shown that elevated activin A in preeclampsia may be responsible for the endothelial dysfunction, which was shown as hypertension, proteiunuria, fetal growth restriction, and preterm littering in activin administered mice [74]. An in vitro study using human umbilical vein endothelial cells (HUVECs) has suggested that activin A up-regulates transcription of endothelial vasoconstrictors such as ET-1 [75]. Moreover, an elevated activin A level had been reported to be strongly correlated with myocardial dysfunction at 1 year after preeclamptic pregnancy, and a recent follow up study confirmed that the activin A level still remained elevated with impaired cardiac function 10 years after preeclamptic pregnancy, implying its potential use as a tool for monitoring women at risk for postpartum CVD [76,77].

\subsection{Hypoxia Inducible Factor}

Hypoxia inducible factor (HIF) is a heterodimer consisting of HIF1- $\alpha$ and HIF2- $\alpha$ subunits, which are regulated by oxygen, and a constitutively expressed HIF1- $\beta$ subunit. In a hypoxic environment, HIF-1 regulates transcription of various genes, including VEGF, TGF- $\beta 3$, and NOS, by binding at their promotor and enhancer regions [36]. HIF expression is shown to be higher in normal pregnancy, probably due to high estrogen and progesterone levels; however, HIF- $1 \alpha$ and HIF- $2 \alpha$ is overexpressed further in preeclampsia in response to RUPP $[78,79]$. Moreover, HIF- $1 \alpha$ upregulates anti-angiogenic factors such as sFlt- 1 , sEng, and ET-1 expressions and AngII and AngII-converting enzyme (ACE) expressions in the lungs and kidney which add on to the abnormal placentation and development of preeclampsia [80]. An animal study with RUPP rats showed that inhibition of HIF-1 $\alpha$ using siRNA reversed the high blood pressure, renal damage, proteinuria, and elevated serum sFlt-1 level [81]. Therefore, the efficacy of using maternal serum level of HIF-1 $\alpha$ as a predictive marker for preeclampsia has been questioned. A recent prospective study showed that high serum HIF- $1 \alpha$ level (above $1.45 \mathrm{MoM}$ ) in the first trimester of pregnancy $\left(11-13^{+6}\right.$ weeks of gestation) was related to development of preeclampsia, which requires further confirmation with large-scaled studies [82].

\subsection{MicroRNAs}

MicroRNAs(miRNAs) are small ( $<25$ nucleotides), single-stranded, non-coding RNAs that regulate gene expression by inhibiting translation. These molecules bind to the untranslated lesion of a target gene and silence their expression [83]. During pregnancy, miRNAs are profusely expressed in the placenta, mainly from villous trophoblasts, and 
play pivotal role in several processes including trophoblast proliferation, immune tolerance, and angiogenesis [84].

Specifically, miR-210 has been reported to be overexpressed in placentas of preeclampsia [85]. Studies have shown that miR-210 is strongly linked with hypoxia related to RUPP which leads to inadequate trophoblast invasion and failure of spiral artery remodeling in preeclampsia [86]. miR-210 is upregulated by HIF which overexpresses it in response uteroplacental hypoxia in order to regulate genes involved in various pathways including angiogenesis, inflammation, and cell proliferation [87]. Another miRNA involved in preeclampsia is miR-155, which has been shown to inhibit cysteine-rich protein 61 (CYR61), an essential angiogenic factor in pregnancy $[88,89]$. A crucial function of CYR61 is related to inducing the expression of VEGF, which is a major pro-angiogenic factor as previously mentioned [87]. Previous studies have shown that CYR61 gene expression is downregulated in preeclamptic placentas compared to those of normal pregnancy, and suggested that increased miR-155 causes inhibition of the CYR61-VEGF pathways, which leads to reduced placental angiogenesis [90].

Additionally, miR-125b is known to be an anti-angiogenic factor which decreases VEGF expression when it is overexpressed [91]. A recent case-control study showed that the maternal plasma level of miR-125b at 12 weeks of gestation is significantly elevated compared to those in normal pregnancy. Moreover, the same study revealed that miR-125b targets trophoblast cell surface antigen-2 (Trop-2) protein in placental tissue, suggesting miR-125b might be involved in development of preeclampsia via modulating Trop-2 expression in the syncitiotrophoblast [92].

The role of miR-21 in preeclampsia has been also newly studied, since it regulates the forkhead box M1 protein (FOXM1), which is expressed in cytotrophoblasts for proliferation and differentiation, responsible for the early placental development [93]. In fact, a study showed that miR-21 is elevated with reduced FOXM1 expression in patients with preeclampsia compared to those in normotensive pregnant women, implying that miR-21 may impede the early placental invasion leading to preeclampsia [94]. These results demonstrate that various miRNAs are involved in the pathway of preeclampsia which implies their potential to become possible future therapeutic targets for treatment of preeclampsia.

\section{Preeclampsia and Future Cardiovascular Health}

As discussed so far, the key mechanism of preeclampsia is disrupted spiral artery remodeling resulting in insufficient blood flow to the placenta, which in turn leads to RUPP. RUPP leads to a change in the level of several factors released by the placenta-mainly an increase of pro-inflammatory and anti-angiogenic factors and a decrease of pro-angiogenic factors - which eventually spread into the maternal circulation (Figure 2); this results in endothelial dysfunction leading to disrupted maternal hemodynamics. Although some aspects of maternal vascular damage return to normal after birth, it has become apparent that the endothelial damage is evidenced to persist beyond the acute disease in pregnancy.

Cardiovascular diseases (CVD) are currently considered as the leading cause of death globally [95]. Women with a history of HPD, including preeclampsia, have a twofold increased risk of future CVD compared with women with normotensive pregnancies [96-100]. HDP, by definition, is development of de novo hypertension after 20 weeks of pregnancy which includes the following 4 categories: (1) preeclampsia/eclampsia; (2) gestational hypertension; (3) chronic hypertension; and (4) preeclampsia/eclampsia variants superimposed on chronic hypertension [101]. The epidemiologic research has reported a significantly rising prevalence of preeclampsia and gestational hypertension (by 25 and 184\%, respectively) in the last decade. The worldwide population based increases in well-known risk factors for preeclampsia such as pre-pregnancy overweight and obesity, diabetes, twin pregnancy, and advanced maternal age are expected to contribute to the growing rates of the overall HDP [102]. Although it is controversial whether gestational hypertension and preeclampsia develop from the same pathophysiological mechanisms, they both share similar pathway which involves placental insufficiency leading to systemic endothelial 
dysfunction [103]. In addition, the rate of progression into preeclampsia ranges from $15 \%$ to $46 \%$ of women diagnosed with gestational hypertension, suggesting that gestational hypertension and preeclampsia may be considered as different stages of a continuous process with an identical pathophysiology of angiogenic imbalance rather than as separate distinct diseases [103].

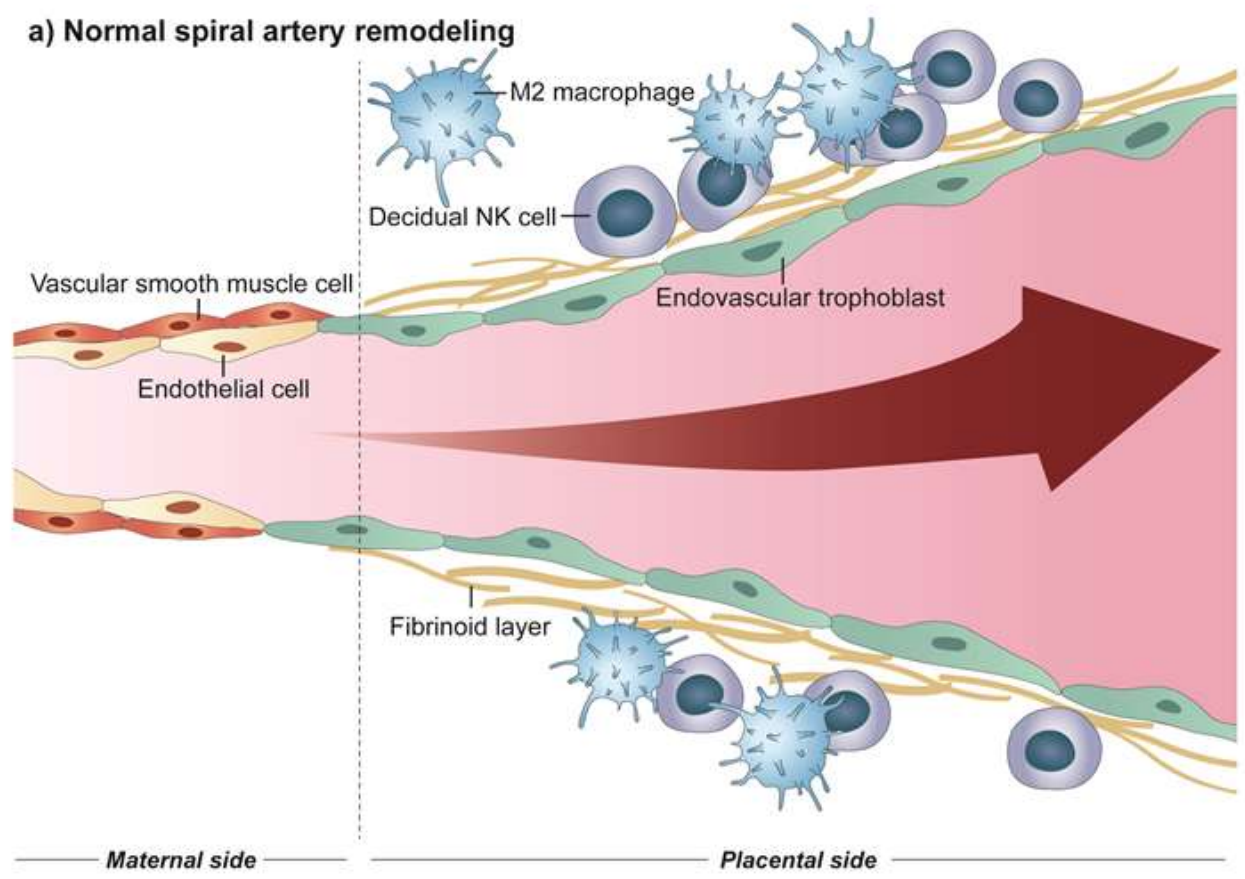

b) Abnormal spiral artery remodeling

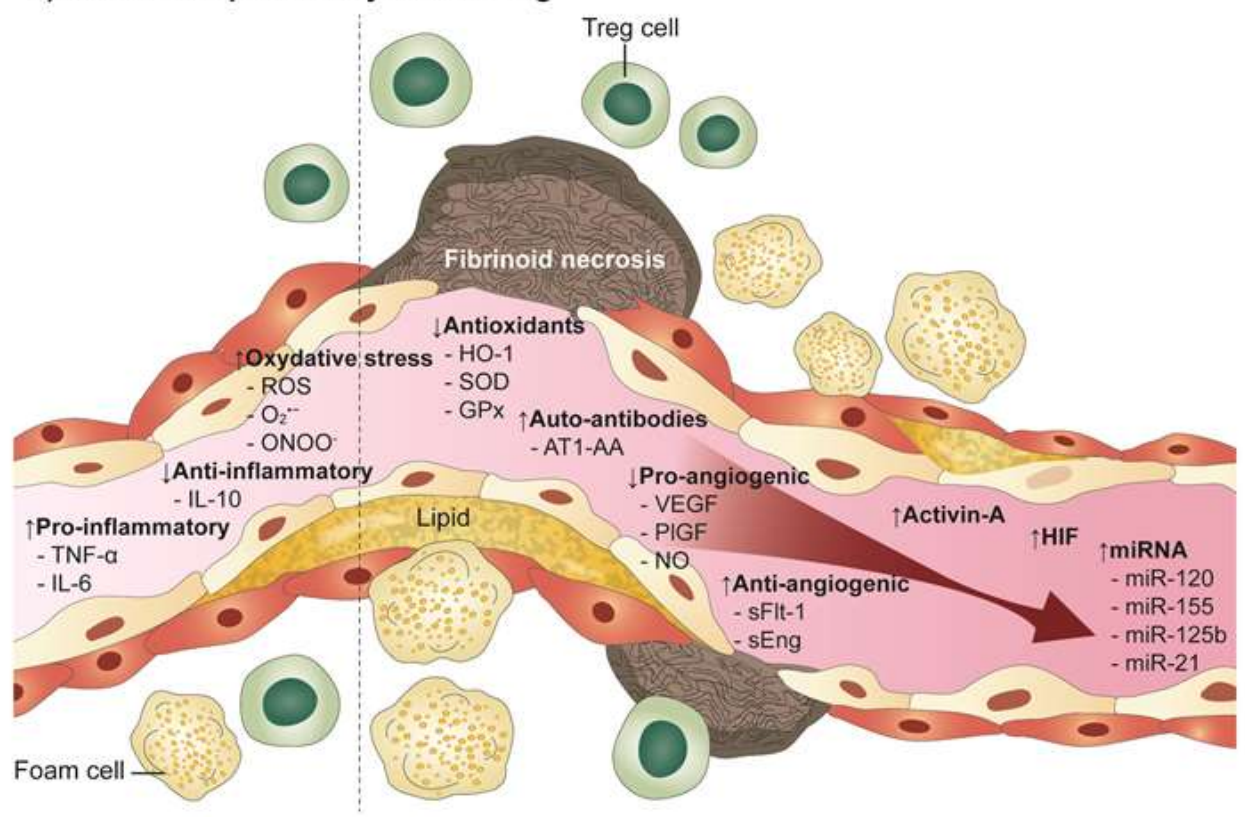

Figure 2. (a) Normal placentation with successful spiral artery remodeling. Endovascular trophoblasts become incorporated into the vessel wall and a fibrinoid layer substitutes the original smooth muscle cell layer, resulting in a low resistance vessel with a newly built thin, flexible wall which brings adequate uteroplacental perfusion. (b) Abnormal spiral artery remodeling in preeclampsia. Failure of endovascular trophoblast invasion results in a relatively narrow, thick-walled tortuous vessel with high resistance leading to reduced uteroplacental perfusion (RUPP). Atherosis is shown with lipid deposition in walls of spiral arteries with lipid-filled foam cells, perivascular lymphocytic infiltration and vascular fibrinoid necrosis. Various molecular factors resulting from RUPP are listed. 
Recently, a history of HDP has been designated as an independent risk factor for future cardiovascular events and incorporated in guidelines for risk stratification of stroke and CVD [104,105]. However, whether HDP serves to unmask a preexisting high CVD risk in an individual or HDP is causally associated with vascular remodeling leading to the development of postpartum CVD remains unclear. The former hypothesis is supported by the fact that HDP and CVD share the preexisting risk factors in common, such as obesity, hypertension, hyperinsulinemia, hyperlipidemia and a family history [106-110]. Therefore, a woman with an already existing high risk of CVD is revealed by the "stress test" of pregnancy as a clinical manifestation of HDP. On the other hand, the latter theory suggests that pro-atherogenic stress of HDP could activate arterial wall inflammation and induce changes in vasculature which may result in future CVD. However, the two mechanisms are not completely exclusive of each other since they both involve endothelial dysfunction caused from vascular maladaptation during pregnancy which we have discussed previously in chapter 4 [111]. Therefore, a history of HDP increases risk of future CVD in a dose dependent manner which depends on how severely the uteroplacental circulation is compromised. The clinical manifestations of HDP with earlier onset, iatrogenic preterm delivery, fetal growth restriction and recurrence of HDP in subsequent pregnancies are related to greater risk of future CVD [112]. In terms of timing, it has been known that within one or two decades after delivery, women with a history of HDP are more likely to experience premature cardiovascular events, such as symptomatic heart failure, myocardial ischemia, and cerebral vascular disease [112,113]. Two systematic reviews and meta-analyses demonstrated that the increased risk for CVD and hypertension is greater during the first 10 years after a pregnancy affected by HDP compared to the risk past 10 years after the affected pregnancy $[97,114]$. Up to one third of women with a history of HDP may develop hypertension within a decade of the affected pregnancy before middle age, indicating that they are more likely to develop CVD at a much younger age compared to controls [115]. Despite the previous belief that the physiological changes and the resulting cardiovascular stress during pregnancy return to pre-pregnancy levels shortly after delivery, the endothelial damage in HDP and its related factors seem to persist and exert long-term consequences on maternal cardiovascular health [116].

\subsection{Chronic Hypertension}

The nationwide register-based cohort study of 1.5 million women who had delivered in Denmark from 1978 to 2012 has reported that women with gestational hypertension had the highest risk of developing chronic hypertension after pregnancy, followed by women with severe preeclampsia and moderate preeclampsia. In fact, of women in their $20 \mathrm{~s}, 14 \%$ of nulliparous women with HDP developed hypertension in the first 10 years after pregnancy compared with $4 \%$ of nulliparous women with normotensive pregnancy. The corresponding percentages of developing hypertension after HDP and without HDP in their forties were higher as expected: $32 \%$ and $11 \%$, respectively. In fact, in a year after delivery, women with HDP had 12-fold to 25-fold higher rates of hypertension compared to women with normotensive pregnancy-which remained high as 3 to 10-fold in the first 10 years after pregnancy and twice higher when it passes 20 years postpartum. The decreasing trend in the relative risk of developing chronic hypertension as time passes from delivery (compared to controls) seem to be due to the natural behavior of hypertension in which its baseline risk increases with age. Therefore, it can be concluded that the risk of hypertension associated with HDP is highest shortly after an affected pregnancy and persists for more than 20 years [115]. The PROSPECT cohort consisting The European Prospective Investigation into Cancer and Nutrition (EPIC)-NL cohort demonstrated that women with HDP reported a diagnosis of hypertension 7.7 years earlier (95\% confidence interval [CI] 6.9-8.5) than women with a normotensive pregnancy, and that women with HDP have an increased risk of developing hypertension (odds ratio 2.12, 95\% CI; 1.98-2.28) [117]. 
The American Heart Association has reported the Heart Disease and Stroke Statistics2021 Update with an enhanced focus on adverse pregnancy outcomes (APO). APOs include HDP, gestational diabetes, preterm delivery, and small for gestational age. These interrelated disorders are associated with long-term risk of cardiometabolic disease in maternal and offspring [118]. While normal pregnancy without APO can be recognized as proper maternal cardiometabolic adaptation, APOs may reflect a maladaptive response to the "stress test" of pregnancy. According to the prospective observational cohort study named Nulliparous Pregnancy Outcomes Study Monitoring Mothers-to-be Heart Health Study, the incidence of APO was 22.7\%, as 1017 out of 4484 females were affected (22.7\%). In this study, the overall incidence of hypertension was 5.4\% (95\% CI; 4.7-6.1\%), with an increased risk among females with any APO (defined as HDP, small-for-gestational-age birth, preterm delivery, and stillbirth) and by subtype (any HDP: Relative risk (RR), 2.7 [95\% CI: 2.0-3.6]; preeclampsia: RR, 2.8 [95\% CI: 2.0-4.0]; preterm delivery; RR, 2.7 [95\% CI: 1.9-3.8]). Among APO, women with both HDP and iatrogenic preterm delivery had the highest risk of hypertension (RR 4.3,95\% CI: 2.7-6.7) in a short-term follow-up over a mean of 3.2 years after the first pregnancy. Under such conditions, chronic hypertension developed in $45.4 \%$ of females [119]. A recurrence rate of developing preeclampsia in the subsequent pregnancy has been reported as 16\% [120]. Recurrent preeclampsia is consistently associated with a higher risk ratio of developing chronic hypertension (RR 2.3, 95\% CI; 1.9-2.9) than women with a subsequent uncomplicated pregnancy after a preeclamptic pregnancy [121]. Other longitudinal prospective studies demonstrated that women with a history of preterm preeclampsia had a higher prevalence of hypertension compared with term preeclampsia [122]. Overall, it has been postulated that HDP affects the future risk of developing chronic hypertension in a dose-dependent manner as mentioned previously, depending on the severity of placental insufficiency which manifests clinically; HDP with earlier onset, severe criteria, preterm delivery, fetal growth restriction or recurrence affects the risk of postpartum hypertension with a greater chance [112].

\subsection{Altered Vascular Structure}

Carotid intima-media thickness (CIMT) is a well validated, non-invasive marker of subclinical atherosclerotic disease. It involves ultrasound evaluation of the thickness of the intimal and medial carotid arterial wall. Data have shown that an increased CIMT confers an elevated risk of coronary atherosclerotic lesions and future cardiovascular disease in both histological and epidemiological studies [123]. Although an assessment of CIMT could reflect arterial remodeling in HDP such as changes in arterial internal diameter and wall thickness, there are only few small-scale studies demonstrating heterogenous results of CIMT assessment in pregnancy.

A prospective study of women with late onset preeclampsia reported a significant increase of $108 \mu \mathrm{m}$ in CIMT compared with those in normotensive pregnancy (459 $\pm 95 \mathrm{vs}$. $351 \pm 85 \mu \mathrm{m}, p=0.0001$ ) [124]. While early onset preeclampsia was also characterized by increased CIMT in another study, it reported that mean CIMT did not differ significantly between the early onset preeclampsia group and the normotensive pregnancy group, but it was significantly increased in the late onset preeclampsia group as compared to controls [125]. On the other hand, another prospective cohort study has identified increased CIMT in only pregnant women with underlying chronic hypertension rather than in women with preeclampsia [126]. Despite the heterogenous study results and inconclusiveness, these studies suggest the possibility that vascular structural changes may reflect vascular remodeling as adaptive response to hypertension during pregnancy.

The coronary artery calcification (CAC) Score assessed by coronary computed tomography (CCT) is another important predictor for CVD events. Calcification is related to arterial stiffness associated with an increased risk of CVD, and the St. Francis Heart study determined that for a CAC score $>100$ Agaston units (AU), the relative risk for atherosclerotic CVD was 9.6 (95\% CI; 6.1-13.9) [123]. Significant coronary atherosclerosis could be identified by imaging the non-calcified coronary plaque with contrast-enhanced 
coronary CT angiography (CCTA) before calcification of plaque occurs [127]. Although there has been no study for evaluation of CAC score during pregnancy due to the fetal risks of radiation exposure, several studies have reported that CAC score is higher in postpartum women with a history of HDP. In the first prospective cohort study, a history of preeclampsia was shown to be associated with an increased risk of CAC $>30$ years after affected pregnancies, even after controlling individually for traditional risk factors. Compared to women with uncomplicated pregnancies, it demonstrated that the odds of having a higher CAC score was 3.54 (CI; 1.39-9.02) times greater in women with prior preeclampsia without adjustment and $2.61(\mathrm{CI} ; 0.95-7.14)$ times greater after adjustment for current hypertension [128]. Regarding asymptomatic women aged 45 to 55 years, it has been also reported that $30 \%$ of women with a history of preeclampsia show features of coronary atherosclerosis on vascular computed tomography imaging as compared to $18 \%$ of women from the reference group [129]. In addition, a recent study showed that women with previous preeclampsia developed CAC about five years earlier than women with normotensive pregnancies [130]. Population based studies also showed that women with a history of preeclampsia develop cardiovascular risk factors, including high blood pressure, dyslipidemia, and diabetes, five to ten years earlier than women without such a history [130]. Therefore, early cardiovascular screening of women with a history of HDP would definitely benefit in reducing future CAD events.

\subsection{Coronary Artery Disease and Cerebrovascular Accident}

Atheromatous plaque is formed through a chronic, inflammatory progression of atherosclerotic disease without overt symptoms. It can result in a sudden occurrence of coronary artery disease (CAD), such as myocardial infarction, unstable angina pectoris and cardiac death [131]. The prevalence of ischemic heart disease in women with a history of HDP is significantly higher than compared to those with a history of normotensive pregnancy $[4,132]$. As it was seen in chronic hypertension discussed previously, HDP also affects future $C A D$ risk depending on its severity, association with $\mathrm{APO}$, and recurrence; these associations remained significant after adjustment for confounding variables $[121,133]$. A previous meta-analysis published in 2017 reported that the future risk of CAD following HDP was not significant after adjustment for pregestational hypertension [95]. However, nine large cohort studies from various countries including Norway, the United Kingdom, Denmark, United States, Canada, and Australia were followed, and a recent systematic review and meta-analysis of 73 studies involving $>13$ million women demonstrated that the overall combined relative risks of CAD for women with a history of HDP compared with the normotensive group was 1.66 (CI;1.49-1.84), along with 1.80 (CI; 1.67-1.94) for any CVD, $2.87(\mathrm{CI} ; 2.14-3.85)$ for heart failure, $1.60(\mathrm{CI} ; 1.29-2.00)$ for peripheral vascular disease, 1.72 (CI;1.50-1.97) for stroke, 1.78 (CI; 1.58-2.00) for CVD-related mortality, and 3.16 (CI; 2.74-3.64) for chronic hypertension [114,133-138].

In addition, the risk ratio of cerebrovascular disease (CD) in women with previous preeclampsia ranged from 1.53 to 3.13 [95,117,139,140]. Regarding women with previous gestational hypertension, a prospective population-based cohort study reported that women with a gestational hypertension had a 1.3-fold (CI; 0.9 to 1.7) higher risk of developing CD compared with women without any HDP [141]. Furthermore, a meta-analysis in 2018 found that recurrent preeclampsia was consistently related to an increased risk ratio of stroke (RR 1.7, CI; 1.2-2.6) when compared with preeclampsia in a single pregnancy followed by subsequent uncomplicated pregnancies [121].

\subsection{Postpartum Management after HDP}

Although the mechanisms still remain elusive, it is evident that the risk of CVD rises after HDP, which can occur early in the postpartum period. As of today, various guidelines for postpartum follow-up are suggested.

The American College of Obstetricians and Gynecologists (ACOG) recommends that all women with HDP have an initial check with their obstetrician within three weeks post- 
partum, followed by another visit at three months postpartum, and annual cardiovascular checkups consequently [142]. A recent recommendation by the American Heart Association suggests initiation of screening for CVD as soon as possible after delivery in women with HDP. The suggested strategies include: (1) an interdisciplinary approach for early identification of CVD risk factors, (2) continuous postpartum visits starting six to eight weeks postpartum and annually thereafter, (3) consistent monitoring of blood pressure and biomarkers at clinic and at home, and (4) educating patients about their individual risk and helpful lifestyle modifications to prevent CVD [143].

\section{Conclusions}

The key mechanism of preeclampsia is defective spiral artery remodeling resulting in inadequate blood flow to the placenta, which in turn leads to RUPP. RUPP leads to rise in pro-inflammatory and anti-angiogenic factors and decrease in pro-angiogenic factor in maternal circulation which in turn results in endothelial dysfunction leading to disrupted maternal hemodynamics. The association between HDP and postpartum CVD has become a well-accepted fact, especially among women with a history of preeclampsia. Risk factors of CVD mostly develop in the early postpartum period and the most vulnerable timing for CVD events is the decade after delivery, in which the related circulating factors persist in maternal circulation. Therefore, women with a history of HDP should be considered for risk evaluation before the current cardiovascular screening guidelines. Although the exact linking mechanisms between HDP and CVD are still left for further research, primary prevention strategies to reduce cardiovascular disease in women should always include risk stratification based on their obstetrical history.

Author Contributions: Conceptualization, H.J.P.; writing-original draft preparation, K.H., S.H.K.; writing-review and editing, K.H., H.J.P., S.H.K., D.H.C.; visualization, K.H., H.J.P., D.H.C.; supervision, H.J.P., D.H.C. All authors have read and agreed to the published version of the manuscript.

Funding: This work was supported by a grant from the Korea Health Technology R\&D Project, funded by the Ministry of Health \& Welfare, Republic of Korea (grant number: HI18C-1839-010019).

Conflicts of Interest: The authors declare no conflict of interest.

\section{References}

1. Brown, M.A.; Magee, L.A.; Kenny, L.C.; Karumanchi, S.A.; McCarthy, F.P.; Saito, S.; Hall, D.R.; Warren, C.E.; Adoyi, G.; Ishaku, S. The hypertensive disorders of pregnancy: ISSHP classification, diagnosis \& management recommendations for international practice. Pregnancy Hypertens. 2018, 13, 291-310. [CrossRef]

2. Brown, M.A.; Magee, L.A.; Kenny, L.C.; Karumanchi, S.A.; McCarthy, F.P.; Saito, S.; Hall, D.R.; Warren, C.E.; Adoyi, G.; Ishaku, S. Hypertensive Disorders of Pregnancy: ISSHP Classification, Diagnosis, and Management Recommendations for International Practice. Hypertension 2018, 72, 24-43. [CrossRef]

3. Mosca, L.; Benjamin, E.J.; Berra, K.; Bezanson, J.L.; Dolor, R.J.; Lloyd-Jones, D.M.; Newby, L.K.; Piña, I.L.; Roger, V.L.; Shaw, L.J.; et al. Effectiveness-Based Guidelines for the Prevention of Cardiovascular Disease in Women-2011 Update. Circulation 2011, 123, 1243-1262. [CrossRef]

4. Bellamy, L.; Casas, J.P.; Hingorani, A.D.; Williams, D.J. Pre-eclampsia and risk of cardiovascular disease and cancer in later life: Systematic review and meta-analysis. BMJ 2007, 335, 974. [CrossRef]

5. Hong, K.; Park, H.J.; Cha, D.H. Clinical implications of placenta-derived angiogenic/anti-angiogenic biomarkers in pre-eclampsia. Biomark. Med. 2021, 15, 523-536. [CrossRef]

6. Lyall, F. The human placental bed revisited. Placenta 2002, 23, 555-562. [CrossRef] [PubMed]

7. Brosens, I.A.; Robertson, W.B.; Dixon, H.G. The role of the spiral arteries in the pathogenesis of preeclampsia. Obstet. Gynecol. Annu. 1972, 1, 177-191. [CrossRef] [PubMed]

8. Pijnenborg, R.; Vercruysse, L.; Hanssens, M. The uterine spiral arteries in human pregnancy: Facts and controversies. Placenta 2006, 27, 939-958. [CrossRef] [PubMed]

9. Sato, Y. Endovascular trophoblast and spiral artery remodeling. Mol. Cell. Endocrinol. 2020, 503, 110699. [CrossRef] [PubMed]

10. Chaiworapongsa, T.; Chaemsaithong, P.; Yeo, L.; Romero, R. Pre-eclampsia part 1: Current understanding of its pathophysiology. Nat. Rev. Nephrol. 2014, 10, 466-480. [CrossRef]

11. Sheppard, B.L.; Bonnar, J. An ultrastructural study of utero-placental spiral arteries in hypertensive and normotensive pregnancy and fetal growth retardation. Br. J. Obstet. Gynaecol. 1981, 88, 695-705. [CrossRef] 
12. Brosens, I.; Pijnenborg, R.; Vercruysse, L.; Romero, R. The "Great Obstetrical Syndromes" are associated with disorders of deep placentation. Am. J. Obstet. Gynecol. 2011, 204, 193-201. [CrossRef]

13. Kim, Y.M.; Chaiworapongsa, T.; Gomez, R.; Bujold, E.; Yoon, B.H.; Rotmensch, S.; Thaler, H.T.; Romero, R. Failure of physiologic transformation of the spiral arteries in the placental bed in preterm premature rupture of membranes. Am. J. Obstet. Gynecol. 2002, 187, 1137-1142. [CrossRef]

14. Romero, R.; Kusanovic, J.P.; Chaiworapongsa, T.; Hassan, S.S. Placental bed disorders in preterm labor, preterm PROM, spontaneous abortion and abruptio placentae. Best Pract. Res. Clin. Obstet. Gynaecol. 2011, 25, 313-327. [CrossRef] [PubMed]

15. Raymond, D.; Peterson, E. A critical review of early-onset and late-onset preeclampsia. Obstet. Gynecol. Surv. 2011, 66, 497-506. [CrossRef] [PubMed]

16. Staff, A.C. The two-stage placental model of preeclampsia: An update. J. Reprod. Immunol. 2019, 134-135, 1-10. [CrossRef] [PubMed]

17. Burton, G.J.; Woods, A.W.; Jauniaux, E.; Kingdom, J.C. Rheological and physiological consequences of conversion of the maternal spiral arteries for uteroplacental blood flow during human pregnancy. Placenta 2009, 30, 473-482. [CrossRef]

18. Potter, J.M.; Nestel, P.J. The hyperlipidemia of pregnancy in normal and complicated pregnancies. Am. J. Obstet. Gynecol. 1979, 133, 165-170. [CrossRef]

19. Belo, L.; Santos-Silva, A.; Quintanilha, A.; Rebelo, I. Similarities between pre-eclampsia and atherosclerosis: A protective effect of physical exercise? Curr. Med. Chem. 2008, 15, 2223-2229. [CrossRef]

20. Labarrere, C.A. Acute atherosis. A histopathological hallmark of immune aggression? Placenta 1988, 9, 95-108. [CrossRef]

21. Labarrere, C.A.; DiCarlo, H.L.; Bammerlin, E.; Hardin, J.W.; Kim, Y.M.; Chaemsaithong, P.; Haas, D.M.; Kassab, G.S.; Romero, R. Failure of physiologic transformation of spiral arteries, endothelial and trophoblast cell activation, and acute atherosis in the basal plate of the placenta. Am. J. Obstet. Gynecol. 2017, 216, 287.e1-287.e16. [CrossRef]

22. Staff, A.C.; Dechend, R.; Pijnenborg, R. Learning from the placenta: Acute atherosis and vascular remodeling in preeclampsianovel aspects for atherosclerosis and future cardiovascular health. Hypertension 2010, 56, 1026-1034. [CrossRef]

23. Alnaes-Katjavivi, P.; Lyall, F.; Roald, B.; Redman, C.W.; Staff, A.C. Acute atherosis in vacuum suction biopsies of decidua basalis: An evidence based research definition. Placenta 2016, 37, 26-33. [CrossRef] [PubMed]

24. Kim, Y.M.; Chaemsaithong, P.; Romero, R.; Shaman, M.; Kim, C.J.; Kim, J.S.; Qureshi, F.; Jacques, S.M.; Ahmed, A.I.; Chaiworapongsa, T.; et al. The frequency of acute atherosis in normal pregnancy and preterm labor, preeclampsia, small-for-gestational age, fetal death and midtrimester spontaneous abortion. J. Matern. Fetal Neonatal. Med. 2015, 28, 2001-2009. [CrossRef] [PubMed]

25. Stevens, D.U.; Al-Nasiry, S.; Bulten, J.; Spaanderman, M.E. Decidual vasculopathy and adverse perinatal outcome in preeclamptic pregnancy. Placenta 2012, 33, 630-633. [CrossRef]

26. Harsem, N.K.; Roald, B.; Braekke, K.; Staff, A.C. Acute atherosis in decidual tissue: Not associated with systemic oxidative stress in preeclampsia. Placenta 2007, 28, 958-964. [CrossRef] [PubMed]

27. Staff, A.C.; Fjeldstad, H.E.; Fosheim, I.K.; Moe, K.; Turowski, G.; Johnsen, G.M.; Alnaes-Katjavivi, P.; Sugulle, M. Failure of physiological transformation and spiral artery atherosis: Their roles in preeclampsia. Am. J. Obstet. Gynecol. 2020. [CrossRef]

28. Moreno-Eutimio, M.A.; Tovar-Rodríguez, J.M.; Vargas-Avila, K.; Nieto-Velázquez, N.G.; Frías-De-León, M.G.; Sierra-Martinez, M.; Acosta-Altamirano, G. Increased serum levels of inflammatory mediators and low frequency of regulatory $\mathrm{T}$ cells in the peripheral blood of preeclamptic Mexican women. Biomed. Res. Int. 2014, 2014, 413249. [CrossRef] [PubMed]

29. Sánchez-Aranguren, L.C.; Prada, C.E.; Riaño-Medina, C.E.; Lopez, M. Endothelial dysfunction and preeclampsia: Role of oxidative stress. Front. Physiol. 2014, 5, 372. [CrossRef]

30. Lockwood, C.J.; Yen, C.F.; Basar, M.; Kayisli, U.A.; Martel, M.; Buhimschi, I.; Buhimschi, C.; Huang, S.J.; Krikun, G.; Schatz, F. Preeclampsia-related inflammatory cytokines regulate interleukin-6 expression in human decidual cells. Am. J. Pathol. 2008, 172, 1571-1579. [CrossRef]

31. Wallace, K.; Richards, S.; Dhillon, P.; Weimer, A.; Edholm, E.S.; Bengten, E.; Wilson, M.; Martin, J.N., Jr.; LaMarca, B. CD4+ T-helper cells stimulated in response to placental ischemia mediate hypertension during pregnancy. Hypertension 2011, 57, 949-955. [CrossRef] [PubMed]

32. Lamarca, B.; Brewer, J.; Wallace, K. IL-6-induced pathophysiology during pre-eclampsia: Potential therapeutic role for magnesium sulfate? Int. J. Interferon. Cytokine Mediat. Res. 2011, 2011, 59-64. [CrossRef]

33. Peixoto, A.B.; Araujo Júnior, E.; Ribeiro, J.U.; Rodrigues, D.B.; Castro, E.C.; Caldas, T.M.; Rodrigues Júnior, V. Evaluation of inflammatory mediators in the deciduas of pregnant women with pre-eclampsia/eclampsia. J. Matern. Fetal Neonatal. Med. 2016, 29, 75-79. [CrossRef] [PubMed]

34. Cornelius, D.C.; Amaral, L.M.; Harmon, A.; Wallace, K.; Thomas, A.J.; Campbell, N.; Scott, J.; Herse, F.; Haase, N.; Moseley, J.; et al. An increased population of regulatory T cells improves the pathophysiology of placental ischemia in a rat model of preeclampsia. Am. J. Physiol. Regul. Integr. Comp. Physiol. 2015, 309, R884-R891. [CrossRef] [PubMed]

35. Nath, M.C.; Cubro, H.; McCormick, D.J.; Milic, N.M.; Garovic, V.D. Preeclamptic Women Have Decreased Circulating IL-10 (Interleukin-10) Values at the Time of Preeclampsia Diagnosis: Systematic Review and Meta-Analysis. Hypertension 2020, 76, 1817-1827. [CrossRef]

36. Shah, D.A.; Khalil, R.A. Bioactive factors in uteroplacental and systemic circulation link placental ischemia to generalized vascular dysfunction in hypertensive pregnancy and preeclampsia. Biochem. Pharmacol. 2015, 95, 211-226. [CrossRef] 
37. Reslan, O.M.; Khalil, R.A. Molecular and vascular targets in the pathogenesis and management of the hypertension associated with preeclampsia. Cardiovasc. Hematol. Agents Med. Chem. 2010, 8, 204-226. [CrossRef]

38. Bainbridge, S.A.; Belkacemi, L.; Dickinson, M.; Graham, C.H.; Smith, G.N. Carbon monoxide inhibits hypoxia/reoxygenationinduced apoptosis and secondary necrosis in syncytiotrophoblast. Am. J. Pathol. 2006, 169, 774-783. [CrossRef]

39. Chambers, J.C.; Fusi, L.; Malik, I.S.; Haskard, D.O.; De Swiet, M.; Kooner, J.S. Association of maternal endothelial dysfunction with preeclampsia. JAMA 2001, 285, 1607-1612. [CrossRef]

40. Sutton, E.F.; Gemmel, M.; Powers, R.W. Nitric oxide signaling in pregnancy and preeclampsia. Nitric Oxide 2020, 95, 55-62. [CrossRef]

41. Guerby, P.; Tasta, O.; Swiader, A.; Pont, F.; Bujold, E.; Parant, O.; Vayssiere, C.; Salvayre, R.; Negre-Salvayre, A. Role of oxidative stress in the dysfunction of the placental endothelial nitric oxide synthase in preeclampsia. Redox Biol. 2021, 40, 101861. [CrossRef] [PubMed]

42. Chassagne, C.; Eddahibi, S.; Adamy, C.; Rideau, D.; Marotte, F.; Dubois-Randé, J.L.; Adnot, S.; Samuel, J.L.; Teiger, E. Modulation of angiotensin II receptor expression during development and regression of hypoxic pulmonary hypertension. Am. J. Respir. Cell. Mol. Biol. 2000, 22, 323-332. [CrossRef] [PubMed]

43. Anton, L.; Merrill, D.C.; Neves, L.A.; Diz, D.I.; Corthorn, J.; Valdes, G.; Stovall, K.; Gallagher, P.E.; Moorefield, C.; Gruver, C.; et al. The uterine placental bed Renin-Angiotensin system in normal and preeclamptic pregnancy. Endocrinology 2009, 150, 4316-4325. [CrossRef]

44. Quitterer, U.; Fu, X.; Pohl, A.; Bayoumy, K.M.; Langer, A.; AbdAlla, S. Beta-Arrestin1 Prevents Preeclampsia by Downregulation of Mechanosensitive AT1-B2 Receptor Heteromers. Cell 2019, 176, 318-333.e19. [CrossRef]

45. Zanaty, M.; Seara, F.A.C.; Nakagawa, P.; Deng, G.; Mathieu, N.M.; Balapattabi, K.; Karnik, S.S.; Grobe, J.L.; Sigmund, C.D. $\beta$-Arrestin-Biased Agonist Targeting the Brain AT(1)R (Angiotensin II Type 1 Receptor) Increases Aversion to Saline and Lowers Blood Pressure in Deoxycorticosterone Acetate-Salt Hypertension. Hypertension 2021, 77, 420-431. [CrossRef]

46. Siddiqui, A.H.; Irani, R.A.; Zhang, W.; Wang, W.; Blackwell, S.C.; Kellems, R.E.; Xia, Y. Angiotensin receptor agonistic autoantibody-mediated soluble fms-like tyrosine kinase-1 induction contributes to impaired adrenal vasculature and decreased aldosterone production in preeclampsia. Hypertension 2013, 61, 472-479. [CrossRef]

47. George, E.M.; Granger, J.P. Endothelin: Key mediator of hypertension in preeclampsia. Am. J. Hypertens. 2011, 24, 964-969. [CrossRef]

48. Novotny, S.R.; Wallace, K.; Heath, J.; Moseley, J.; Dhillon, P.; Weimer, A.; Wallukat, G.; Herse, F.; Wenzel, K.; Martin, J.N., Jr.; et al. Activating autoantibodies to the angiotensin II type I receptor play an important role in mediating hypertension in response to adoptive transfer of CD4+ T lymphocytes from placental ischemic rats. Am. J. Physiol. Regul. Integr. Comp. Physiol. 2012, 302, R1197-R1201. [CrossRef]

49. Hubel, C.A.; Wallukat, G.; Wolf, M.; Herse, F.; Rajakumar, A.; Roberts, J.M.; Markovic, N.; Thadhani, R.; Luft, F.C.; Dechend, R. Agonistic angiotensin II type 1 receptor autoantibodies in postpartum women with a history of preeclampsia. Hypertension 2007, 49, 612-617. [CrossRef] [PubMed]

50. Rieber-Mohn, A.B.; Sugulle, M.; Wallukat, G.; Alnæs-Katjavivi, P.; Leite Størvold, G.; Bolstad, N.; Redman, C.W.; Dechend, R.; Staff, A.C. Auto-antibodies against the angiotensin II type I receptor in women with uteroplacental acute atherosis and preeclampsia at delivery and several years postpartum. J. Reprod. Immunol. 2018, 128, 23-29. [CrossRef] [PubMed]

51. Bdolah, Y.; Sukhatme, V.P.; Karumanchi, S.A. Angiogenic imbalance in the pathophysiology of preeclampsia: Newer insights. Semin. Nephrol. 2004, 24, 548-556. [CrossRef] [PubMed]

52. Boeldt, D.S.; Bird, I.M. Vascular adaptation in pregnancy and endothelial dysfunction in preeclampsia. J. Endocrinol. 2017, 232, R27-R44. [CrossRef] [PubMed]

53. Charnock-Jones, D.S.; Sharkey, A.M.; Boocock, C.A.; Ahmed, A.; Plevin, R.; Ferrara, N.; Smith, S.K. Vascular endothelial growth factor receptor localization and activation in human trophoblast and choriocarcinoma cells. Biol. Reprod. 1994, 51, 524-530. [CrossRef] [PubMed]

54. Athanassiades, A.; Hamilton, G.S.; Lala, P.K. Vascular endothelial growth factor stimulates proliferation but not migration or invasiveness in human extravillous trophoblast. Biol. Reprod. 1998, 59, 643-654. [CrossRef] [PubMed]

55. Maynard, S.E.; Min, J.Y.; Merchan, J.; Lim, K.H.; Li, J.; Mondal, S.; Libermann, T.A.; Morgan, J.P.; Sellke, F.W.; Stillman, I.E.; et al. Excess placental soluble fms-like tyrosine kinase 1 (sFlt1) may contribute to endothelial dysfunction, hypertension, and proteinuria in preeclampsia. J. Clin. Investig. 2003, 111, 649-658. [CrossRef] [PubMed]

56. Gilbert, J.S.; Babcock, S.A.; Granger, J.P. Hypertension produced by reduced uterine perfusion in pregnant rats is associated with increased soluble fms-like tyrosine kinase-1 expression. Hypertension 2007, 50, 1142-1147. [CrossRef] [PubMed]

57. Albonici, L.; Giganti, M.G.; Modesti, A.; Manzari, V.; Bei, R. Multifaceted Role of the Placental Growth Factor (PlGF) in the Antitumor Immune Response and Cancer Progression. Int. J. Mol. Sci. 2019, 20, 2970. [CrossRef] [PubMed]

58. March, M.I.; Geahchan, C.; Wenger, J.; Raghuraman, N.; Berg, A.; Haddow, H.; McKeon, B.A.; Narcisse, R.; David, J.L.; Scott, J.; et al. Circulating Angiogenic Factors and the Risk of Adverse Outcomes among Haitian Women with Preeclampsia. PLoS ONE 2015, 10, e0126815. [CrossRef]

59. National Institute for Health and Care Excellence: Clinical Guidelines. Hypertension in Pregnancy: Diagnosis and Management; National Institute for Health and Care Excellence: London, UK, 2019. 
60. Wulff, C.; Wilson, H.; Dickson, S.E.; Wiegand, S.J.; Fraser, H.M. Hemochorial placentation in the primate: Expression of vascular endothelial growth factor, angiopoietins, and their receptors throughout pregnancy. Biol. Reprod. 2002, 66, 802-812. [CrossRef]

61. Geva, E.; Ginzinger, D.G.; Zaloudek, C.J.; Moore, D.H.; Byrne, A.; Jaffe, R.B. Human placental vascular development: Vasculogenic and angiogenic (branching and nonbranching) transformation is regulated by vascular endothelial growth factor-A, angiopoietin1, and angiopoietin-2. J. Clin. Endocrinol. Metab. 2002, 87, 4213-4224. [CrossRef]

62. Kendall, R.L.; Thomas, K.A. Inhibition of vascular endothelial cell growth factor activity by an endogenously encoded soluble receptor. Proc. Natl. Acad. Sci. USA 1993, 90, 10705-10709. [CrossRef]

63. Sircar, M.; Thadhani, R.; Karumanchi, S.A. Pathogenesis of preeclampsia. Curr. Opin. Nephrol. Hypertens. 2015, $24,131-138$. [CrossRef]

64. Verlohren, S.; Herraiz, I.; Lapaire, O.; Schlembach, D.; Zeisler, H.; Calda, P.; Sabria, J.; Markfeld-Erol, F.; Galindo, A.; Schoofs, K.; et al. New gestational phase-specific cutoff values for the use of the soluble fms-like tyrosine kinase- 1 /placental growth factor ratio as a diagnostic test for preeclampsia. Hypertension 2014, 63, 346-352. [CrossRef]

65. Lim, S.; Li, W.; Kemper, J.; Nguyen, A.; Mol, B.W.; Reddy, M. Biomarkers and the Prediction of Adverse Outcomes in Preeclampsia: A Systematic Review and Meta-analysis. Obstet. Gynecol. 2021, 137, 72-81. [CrossRef]

66. Cheifetz, S.; Bellón, T.; Calés, C.; Vera, S.; Bernabeu, C.; Massagué, J.; Letarte, M. Endoglin is a component of the transforming growth factor-beta receptor system in human endothelial cells. J. Biol. Chem. 1992, 267, 19027-19030. [CrossRef]

67. Goumans, M.J.; Valdimarsdottir, G.; Itoh, S.; Rosendahl, A.; Sideras, P.; ten Dijke, P. Balancing the activation state of the endothelium via two distinct TGF-beta type I receptors. EMBO J. 2002, 21, 1743-1753. [CrossRef] [PubMed]

68. Park, S.; Sorenson, C.M.; Sheibani, N. PECAM-1 isoforms, eNOS and endoglin axis in regulation of angiogenesis. Clin. Sci. 2015, 129, 217-234. [CrossRef]

69. Venkatesha, S.; Toporsian, M.; Lam, C.; Hanai, J.; Mammoto, T.; Kim, Y.M.; Bdolah, Y.; Lim, K.H.; Yuan, H.T.; Libermann, T.A.; et al. Soluble endoglin contributes to the pathogenesis of preeclampsia. Nat. Med. 2006, 12, 642-649. [CrossRef] [PubMed]

70. Rabinovici, J.; Goldsmith, P.C.; Librach, C.L.; Jaffe, R.B. Localization and regulation of the activin-A dimer in human placental cells. J. Clin. Endocrinol. Metab. 1992, 75, 571-576. [CrossRef] [PubMed]

71. Muttukrishna, S.; Knight, P.G.; Groome, N.P.; Redman, C.W.; Ledger, W.L. Activin A and inhibin A as possible endocrine markers for pre-eclampsia. Lancet 1997, 349, 1285-1288. [CrossRef]

72. Manuelpillai, U.; Schneider-Kolsky, M.; Dole, A.; Wallace, E.M. Activin A and activin receptors in gestational tissue from preeclamptic pregnancies. J. Endocrinol. 2001, 171, 57-64. [CrossRef]

73. Muttukrishna, S.; North, R.A.; Morris, J.; Schellenberg, J.C.; Taylor, R.S.; Asselin, J.; Ledger, W.; Groome, N.; Redman, C.W. Serum inhibin A and activin A are elevated prior to the onset of pre-eclampsia. Hum. Reprod. 2000, 15, 1640-1645. [CrossRef]

74. Lim, R.; Acharya, R.; Delpachitra, P.; Hobson, S.; Sobey, C.G.; Drummond, G.R.; Wallace, E.M. Activin and NADPH-oxidase in preeclampsia: Insights from in vitro and murine studies. Am. J. Obstet. Gynecol. 2015, 212, 86.e1-86.e12. [CrossRef]

75. Hobson, S.R.; Lim, R.; Mockler, J.C.; Gurusinghe, S.; Wallace, E.M. Role of Activin A in the Pathogenesis of Endothelial Cell Dysfunction in Preeclampsia. Methods Mol. Biol. 2018, 1710, 39-52. [CrossRef] [PubMed]

76. Shahul, S.; Ramadan, H.; Nizamuddin, J.; Mueller, A.; Patel, V.; Dreixler, J.; Tung, A.; Lang, R.M.; Weinert, L.; Nasim, R.; et al. Activin A and Late Postpartum Cardiac Dysfunction Among Women With Hypertensive Disorders of Pregnancy. Hypertension 2018, 72, 188-193. [CrossRef] [PubMed]

77. de Martelly, V.A.; Dreixler, J.; Tung, A.; Mueller, A.; Heimberger, S.; Fazal, A.A.; Naseem, H.; Lang, R.; Kruse, E.; Yamat, M.; et al. Long-Term Postpartum Cardiac Function and Its Association With Preeclampsia. J. Am. Heart Assoc. 2021, 10, e018526. [CrossRef] [PubMed]

78. Daikoku, T.; Matsumoto, H.; Gupta, R.A.; Das, S.K.; Gassmann, M.; DuBois, R.N.; Dey, S.K. Expression of hypoxia-inducible factors in the peri-implantation mouse uterus is regulated in a cell-specific and ovarian steroid hormone-dependent manner. Evidence for differential function of HIFs during early pregnancy. J. Biol. Chem. 2003, 278, 7683-7691. [CrossRef] [PubMed]

79. Akhilesh, M.; Mahalingam, V.; Nalliah, S.; Ali, R.M.; Ganesalingam, M.; Haleagrahara, N. Hypoxia-inducible factor-1 $\alpha$ as a predictive marker in pre-eclampsia. Biomed. Rep. 2013, 1, 257-258. [CrossRef] [PubMed]

80. Tal, R. The role of hypoxia and hypoxia-inducible factor-1alpha in preeclampsia pathogenesis. Biol. Reprod. 2012, 87, 134. [CrossRef]

81. Iriyama, T.; Wang, W.; Parchim, N.F.; Song, A.; Blackwell, S.C.; Sibai, B.M.; Kellems, R.E.; Xia, Y. Hypoxia-independent upregulation of placental hypoxia inducible factor- $1 \alpha$ gene expression contributes to the pathogenesis of preeclampsia. Hypertension 2015, 65, 1307-1315. [CrossRef]

82. Tianthong, W.; Phupong, V. Serum hypoxia-inducible factor- $1 \alpha$ and uterine artery Doppler ultrasound during the first trimester for prediction of preeclampsia. Sci. Rep. 2021, 11, 6674. [CrossRef] [PubMed]

83. Krek, A.; Grün, D.; Poy, M.N.; Wolf, R.; Rosenberg, L.; Epstein, E.J.; MacMenamin, P.; da Piedade, I.; Gunsalus, K.C.; Stoffel, M.; et al. Combinatorial microRNA target predictions. Nat. Genet. 2005, 37, 495-500. [CrossRef] [PubMed]

84. Li, H.; Ge, Q.; Guo, L.; Lu, Z. Maternal plasma miRNAs expression in preeclamptic pregnancies. Biomed. Res. Int. 2013, 2013, 970265. [CrossRef] [PubMed]

85. Pineles, B.L.; Romero, R.; Montenegro, D.; Tarca, A.L.; Han, Y.M.; Kim, Y.M.; Draghici, S.; Espinoza, J.; Kusanovic, J.P.; Mittal, P.; et al. Distinct subsets of microRNAs are expressed differentially in the human placentas of patients with preeclampsia. Am J. Obstet. Gynecol. 2007, 196, 261.e1-261.e6. [CrossRef] [PubMed] 
86. Zhang, Y.; Fei, M.; Xue, G.; Zhou, Q.; Jia, Y.; Li, L.; Xin, H.; Sun, S. Elevated levels of hypoxia-inducible microRNA-210 in pre-eclampsia: New insights into molecular mechanisms for the disease. J. Cell. Mol. Med. 2012, 16, 249-259. [CrossRef]

87. Bounds, K.R.; Chiasson, V.L.; Pan, L.J.; Gupta, S.; Chatterjee, P. MicroRNAs: New Players in the Pathobiology of Preeclampsia. Front. Cardiovasc. Med. 2017, 4, 60. [CrossRef]

88. Lázár, L.; Rigó, J. PP088. The role of microRNA in pathogenesis of preeclampsia-miRNA network analysis. Pregnancy Hypertens. 2013, 3, 99. [CrossRef]

89. Zhang, Y.; Diao, Z.; Su, L.; Sun, H.; Li, R.; Cui, H.; Hu, Y. MicroRNA-155 contributes to preeclampsia by down-regulating CYR61. Am. J. Obstet. Gynecol. 2010, 202, 466.e1-466.e7. [CrossRef]

90. Gellhaus, A.; Schmidt, M.; Dunk, C.; Lye, S.J.; Kimmig, R.; Winterhager, E. Decreased expression of the angiogenic regulators CYR61 (CCN1) and NOV (CCN3) in human placenta is associated with pre-eclampsia. Mol. Hum. Reprod. 2006, 12, 389-399. [CrossRef]

91. He, J.; Jing, Y.; Li, W.; Qian, X.; Xu, Q.; Li, F.S.; Liu, L.Z.; Jiang, B.H.; Jiang, Y. Roles and mechanism of miR-199a and miR-125b in tumor angiogenesis. PLoS ONE 2013, 8, e56647. [CrossRef]

92. Licini, C.; Avellini, C.; Picchiassi, E.; Mensà, E.; Fantone, S.; Ramini, D.; Tersigni, C.; Tossetta, G.; Castellucci, C.; Tarquini, F.; et al Pre-eclampsia predictive ability of maternal miR-125b: A clinical and experimental study. Transl. Res. 2021, 228, 13-27. [CrossRef]

93. Gao, F.; Bian, F.; Ma, X.; Kalinichenko, V.V.; Das, S.K. Control of regional decidualization in implantation: Role of FoxM1 downstream of Hoxa10 and cyclin D3. Sci. Rep. 2015, 5, 13863. [CrossRef]

94. Zhou, F.; Sun, Y.; Gao, Q.; Wang, H. microRNA-21 regulates the proliferation of placental cells via FOXM1 in preeclampsia. Exp. Ther. Med. 2020, 20, 1871-1878. [CrossRef]

95. Wu, P.; Haththotuwa, R.; Kwok, C.S.; Babu, A.; Kotronias, R.A.; Rushton, C.; Zaman, A.; Fryer, A.A.; Kadam, U.; Chew-Graham, C.A.; et al. Preeclampsia and Future Cardiovascular Health: A Systematic Review and Meta-Analysis. Circ. Cardiovasc. Qual. Outcomes 2017, 10, e003497. [CrossRef]

96. Brown, M.C.; Best, K.E.; Pearce, M.S.; Waugh, J.; Robson, S.C.; Bell, R. Cardiovascular disease risk in women with pre-eclampsia: Systematic review and meta-analysis. Eur. J. Epidemiol. 2013, 28, 1-19. [CrossRef]

97. Lo, C.C.W.; Lo, A.C.Q.; Leow, S.H.; Fisher, G.; Corker, B.; Batho, O.; Morris, B.; Chowaniec, M.; Vladutiu, C.J.; Fraser, A.; et al. Future Cardiovascular Disease Risk for Women With Gestational Hypertension: A Systematic Review and Meta-Analysis. J. Am. Heart Assoc. 2020, 9, e013991. [CrossRef]

98. Okoth, K.; Chandan, J.S.; Marshall, T.; Thangaratinam, S.; Thomas, G.N.; Nirantharakumar, K.; Adderley, N.J. Association between the reproductive health of young women and cardiovascular disease in later life: Umbrella review. BMJ 2020, 371, m3502. [CrossRef]

99. McDonald, S.D.; Malinowski, A.; Zhou, Q.; Yusuf, S.; Devereaux, P.J. Cardiovascular sequelae of preeclampsia/eclampsia: A systematic review and meta-analyses. Am. Heart J. 2008, 156, 918-930. [CrossRef] [PubMed]

100. Chen, C.W.; Jaffe, I.Z.; Karumanchi, S.A. Pre-eclampsia and cardiovascular disease. Cardiovasc. Res. 2014, 101, 579-586. [CrossRef] [PubMed]

101. Hypertension in Pregnancy. Report of the American College of Obstetricians and Gynecologists' Task Force on Hypertension in Pregnancy. Obstet. Gynecol. 2013, 122, 1122-1131. [CrossRef]

102. Wallis, A.B.; Saftlas, A.F.; Hsia, J.; Atrash, H.K. Secular Trends in the Rates of Preeclampsia, Eclampsia, and Gestational Hypertension, United States, 1987-2004. Am. J. Hypertens. 2008, 21, 521-526. [CrossRef] [PubMed]

103. Leaños-Miranda, A.; Méndez-Aguilar, F.; Ramírez-Valenzuela, K.L.; Serrano-Rodríguez, M.; Berumen-Lechuga, G.; Molina-Pérez, C.J.; Isordia-Salas, I.; Campos-Galicia, I. Circulating angiogenic factors are related to the severity of gestational hypertension and preeclampsia, and their adverse outcomes. Medicine 2017, 96, e6005. [CrossRef] [PubMed]

104. Bushnell, C.; McCullough, L.D.; Awad, I.A.; Chireau, M.V.; Fedder, W.N.; Furie, K.L.; Howard, V.J.; Lichtman, J.H.; Lisabeth, L.D.; Piña, I.L.; et al. Guidelines for the Prevention of Stroke in Women. Stroke 2014, 45, 1545-1588. [CrossRef] [PubMed]

105. Goldstein, L.B.; Bushnell, C.D.; Adams, R.J.; Appel, L.J.; Braun, L.T.; Chaturvedi, S.; Creager, M.A.; Culebras, A.; Eckel, R.H.; Hart, R.G.; et al. Guidelines for the primary prevention of stroke: A guideline for healthcare professionals from the American Heart Association/American Stroke Association. Stroke 2011, 42, 517-584. [CrossRef] [PubMed]

106. Haug, E.B.; Horn, J.; Markovitz, A.R.; Fraser, A.; Vatten, L.J.; Macdonald-Wallis, C.; Tilling, K.; Romundstad, P.R.; Rich-Edwards, J.W.; Åsvold, B.O. Life Course Trajectories of Cardiovascular Risk Factors in Women With and Without Hypertensive Disorders in First Pregnancy: The HUNT Study in Norway. J. Am. Heart Assoc. 2018, 7, e009250. [CrossRef]

107. Egeland, G.M.; Klungsøyr, K.; Øyen, N.; Tell, G.S.; Næss, Ø.; Skjærven, R. Preconception cardiovascular risk factor differences between gestational hypertension and preeclampsia: Cohort Norway Study. Hypertension 2016, 67, 1173-1180. [CrossRef]

108. Berends, A.L.; de Groot, C.J.; Sijbrands, E.J.; Sie, M.P.; Benneheij, S.H.; Pal, R.; Heydanus, R.; Oostra, B.A.; van Duijn, C.M.; Steegers, E.A. Shared constitutional risks for maternal vascular-related pregnancy complications and future cardiovascular disease. Hypertension 2008, 51, 1034-1041. [CrossRef]

109. Craici, I.; Wagner, S.; Garovic, V.D. Preeclampsia and future cardiovascular risk: Formal risk factor or failed stress test? Ther. Adv. Cardiovasc. Dis. 2008, 2, 249-259. [CrossRef]

110. Rodie, V.A.; Freeman, D.J.; Sattar, N.; Greer, I.A. Pre-eclampsia and cardiovascular disease: Metabolic syndrome of pregnancy? Atherosclerosis 2004, 175, 189-202. [CrossRef] 
111. Staff, A.C.; Redman, C.W.G. IFPA Award in Placentology Lecture: Preeclampsia, the decidual battleground and future maternal cardiovascular disease. Placenta 2014, 35, S26-S31. [CrossRef]

112. Melchiorre, K.; Thilaganathan, B.; Giorgione, V.; Ridder, A.; Memmo, A.; Khalil, A. Hypertensive Disorders of Pregnancy and Future Cardiovascular Health. Front. Cardiovasc. Med. 2020, 7, 59. [CrossRef]

113. Barr, L.C.; Liblik, K.; Johri, A.M.; Smith, G.N. Maternal Cardiovascular Function following a Pregnancy Complicated by Preeclampsia. Am. J. Perinatol. 2020. [CrossRef]

114. Wu, R.; Wang, T.; Gu, R.; Xing, D.; Ye, C.; Chen, Y.; Liu, X.; Chen, L. Hypertensive Disorders of Pregnancy and Risk of Cardiovascular Disease-Related Morbidity and Mortality: A Systematic Review and Meta-Analysis. Cardiology 2020, 145, 633-647. [CrossRef]

115. Behrens, I.; Basit, S.; Melbye, M.; Lykke, J.A.; Wohlfahrt, J.; Bundgaard, H.; Thilaganathan, B.; Boyd, H.A. Risk of post-pregnancy hypertension in women with a history of hypertensive disorders of pregnancy: Nationwide cohort study. BMJ 2017, 358, j3078. [CrossRef] [PubMed]

116. Grandi, S.M.; Filion, K.B.; Yoon, S.; Ayele, H.T.; Doyle, C.M.; Hutcheon, J.A.; Smith, G.N.; Gore, G.C.; Ray, J.G.; Nerenberg, K.; et al. Cardiovascular Disease-Related Morbidity and Mortality in Women With a History of Pregnancy Complications. Circulation 2019, 139, 1069-1079. [CrossRef] [PubMed]

117. Heida, K.Y.; Franx, A.; van Rijn, B.B.; Eijkemans, M.J.; Boer, J.M.; Verschuren, M.W.; Oudijk, M.A.; Bots, M.L.; van der Schouw, Y.T. Earlier Age of Onset of Chronic Hypertension and Type 2 Diabetes Mellitus After a Hypertensive Disorder of Pregnancy or Gestational Diabetes Mellitus. Hypertension 2015, 66, 1116-1122. [CrossRef] [PubMed]

118. Virani, S.S.; Alonso, A.; Aparicio, H.J.; Benjamin, E.J.; Bittencourt, M.S.; Callaway, C.W.; Carson, A.P.; Chamberlain, A.M.; Cheng, S.; Delling, F.N.; et al. Heart Disease and Stroke Statistics-2021 Update: A Report From the American Heart Association. Circulation 2021, 143, e254-e743. [CrossRef]

119. Haas, D.M.; Parker, C.B.; Marsh, D.J.; Grobman, W.A.; Ehrenthal, D.B.; Greenland, P.; Bairey Merz, C.N.; Pemberton, V.L.; Silver, R.M.; Barnes, S.; et al. Association of Adverse Pregnancy Outcomes With Hypertension 2 to 7 Years Postpartum. J. Am. Heart Assoc. 2019, 8, e013092. [CrossRef]

120. Foo, L.; Tay, J.; Lees, C.C.; McEniery, C.M.; Wilkinson, I.B. Hypertension in pregnancy: Natural history and treatment options. Curr. Hypertens. Rep. 2015, 17, 36. [CrossRef]

121. Brouwers, L.; van der Meiden-van Roest, A.J.; Savelkoul, C.; Vogelvang, T.E.; Lely, A.T.; Franx, A.; van Rijn, B.B. Recurrence of pre-eclampsia and the risk of future hypertension and cardiovascular disease: A systematic review and meta-analysis. BJOG 2018, 125, 1642-1654. [CrossRef]

122. Melchiorre, K.; Sutherland, G.R.; Liberati, M.; Thilaganathan, B. Preeclampsia is associated with persistent postpartum cardiovascular impairment. Hypertension 2011, 58, 709-715. [CrossRef]

123. Kirollos, S.; Skilton, M.; Patel, S.; Arnott, C. A Systematic Review of Vascular Structure and Function in Pre-eclampsia: Noninvasive Assessment and Mechanistic Links. Front. Cardiovasc. Med. 2019, 6, 166. [CrossRef]

124. Yuan, L.J.; Xue, D.; Duan, Y.Y.; Cao, T.S.; Yang, H.G.; Zhou, N. Carotid arterial intima-media thickness and arterial stiffness in pre-eclampsia: Analysis with a radiofrequency ultrasound technique. Ultrasound Obstet. Gynecol. 2013, 42, 644-652. [CrossRef] [PubMed]

125. Stergiotou, I.; Crispi, F.; Valenzuela-Alcaraz, B.; Bijnens, B.; Gratacos, E. Patterns of maternal vascular remodeling and responsiveness in early- versus late-onset preeclampsia. Am. J. Obstet. Gynecol. 2013, 209, 558.e1-558.e14. [CrossRef] [PubMed]

126. Mori, T.; Watanabe, K.; Iwasaki, A.; Kimura, C.; Matsushita, H.; Shinohara, K.; Wakatsuki, A. Differences in vascular reactivity between pregnant women with chronic hypertension and preeclampsia. Hypertens. Res. 2014, 37, 145-150. [CrossRef] [PubMed]

127. Zoet, G.A.; Meun, C.; Benschop, L.; Boersma, E.; Budde, R.P.J.; Fauser, B.; de Groot, C.J.M.; van der Lugt, A.; Maas, A.; Moons, K.G.M.; et al. Cardiovascular RiskprofilE-IMaging and gender-specific disOrders (CREw-IMAGO): Rationale and design of a multicenter cohort study. BMC Womens Health 2017, 17, 60. [CrossRef] [PubMed]

128. White, W.M.; Mielke, M.M.; Araoz, P.A.; Lahr, B.D.; Bailey, K.R.; Jayachandran, M.; Miller, V.M.; Garovic, V.D. A history of preeclampsia is associated with a risk for coronary artery calcification 3 decades later. Am. J. Obstet. Gynecol. 2016, $214,519$. [CrossRef] [PubMed]

129. Zoet, G.A.; Benschop, L.; Boersma, E.; Budde, R.P.J.; Fauser, B.; van der Graaf, Y.; de Groot, C.J.M.; Maas, A.; Roeters van Lennep, J.E.; Steegers, E.A.P.; et al. Prevalence of Subclinical Coronary Artery Disease Assessed by Coronary Computed Tomography Angiography in 45- to 55-Year-Old Women With a History of Preeclampsia. Circulation 2018, 137, 877-879. [CrossRef] [PubMed]

130. Benschop, L.; Brouwers, L.; Zoet, G.A.; Meun, C.; Boersma, E.; Budde, R.P.J.; Fauser, B.; de Groot, C.M.J.; van der Schouw, Y.T.; Maas, A.; et al. Early Onset of Coronary Artery Calcification in Women With Previous Preeclampsia. Circ. Cardiovasc. Imaging 2020, 13, e010340. [CrossRef]

131. Toth, P.P. Subclinical atherosclerosis: What it is, what it means and what we can do about it. Int. J. Clin. Pract. 2008, 62, 1246-1254. [CrossRef]

132. Benschop, L.; Duvekot, J.J.; Roeters van Lennep, J.E. Future risk of cardiovascular disease risk factors and events in women after a hypertensive disorder of pregnancy. Heart 2019, 105, 1273-1278. [CrossRef]

133. Riise, H.K.R.; Sulo, G.; Tell, G.S.; Igland, J.; Egeland, G.; Nygard, O.; Selmer, R.; Iversen, A.C.; Daltveit, A.K. Hypertensive pregnancy disorders increase the risk of maternal cardiovascular disease after adjustment for cardiovascular risk factors. Int. J. Cardiol. 2019, 282, 81-87. [CrossRef] [PubMed] 
134. Haug, E.B.; Horn, J.; Markovitz, A.R.; Fraser, A.; Klykken, B.; Dalen, H.; Vatten, L.J.; Romundstad, P.R.; Rich-Edwards, J.W.; Åsvold, B.O. Association of Conventional Cardiovascular Risk Factors With Cardiovascular Disease After Hypertensive Disorders of Pregnancy: Analysis of the Nord-Trøndelag Health Study. JAMA Cardiol. 2019, 4, 628-635. [CrossRef] [PubMed]

135. Behrens, I.; Basit, S.; Lykke, J.A.; Ranthe, M.F.; Wohlfahrt, J.; Bundgaard, H.; Melbye, M.; Boyd, H.A. Association Between Hypertensive Disorders of Pregnancy and Later Risk of Cardiomyopathy. JAMA 2016, 315, 1026-1033. [CrossRef] [PubMed]

136. Stuart, J.J.; Tanz, L.J.; Missmer, S.A.; Rimm, E.B.; Spiegelman, D.; James-Todd, T.M.; Rich-Edwards, J.W. Hypertensive Disorders of Pregnancy and Maternal Cardiovascular Disease Risk Factor Development: An Observational Cohort Study. Ann. Intern. Med. 2018, 169, 224-232. [CrossRef]

137. Auger, N.; Fraser, W.D.; Schnitzer, M.; Leduc, L.; Healy-Profitós, J.; Paradis, G. Recurrent pre-eclampsia and subsequent cardiovascular risk. Heart 2017, 103, 235-243. [CrossRef]

138. Tooher, J.; Thornton, C.; Makris, A.; Ogle, R.; Korda, A.; Horvath, J.; Hennessy, A. Hypertension in pregnancy and long-term cardiovascular mortality: A retrospective cohort study. Am. J. Obstet. Gynecol. 2016, 214, 722.e1-722.e6. [CrossRef]

139. Hiersch, L.; Ray, J.G.; Barrett, J.; Berger, H.; Geary, M.; McDonald, S.D.; Diong, C.; Gandhi, S.; Guan, J.; Murray-Davis, B.; et al Maternal cardiovascular disease after twin pregnancies complicated by hypertensive disorders of pregnancy: A population-based cohort study. Cmaj 2021, 193, E1448-E1458. [CrossRef]

140. McDonald, S.D.; Han, Z.; Walsh, M.W.; Gerstein, H.C.; Devereaux, P.J. Kidney disease after preeclampsia: A systematic review and meta-analysis. Am. J. Kidney Dis. 2010, 55, 1026-1039. [CrossRef]

141. Riise, H.K.R.; Sulo, G.; Tell, G.S.; Igland, J.; Nygård, O.; Iversen, A.C.; Daltveit, A.K. Association Between Gestational Hypertension and Risk of Cardiovascular Disease Among 617,589 Norwegian Women. J. Am. Heart Assoc. 2018, 7, e008337. [CrossRef]

142. ACOG Committee Opinion No. 736: Optimizing Postpartum Care. Obstet. Gynecol. 2018, 131, e140-e150. [CrossRef]

143. Khosla, K.; Heimberger, S.; Nieman, K.M.; Tung, A.; Shahul, S.; Staff, A.C.; Rana, S. Long-Term Cardiovascular Disease Risk in Women After Hypertensive Disorders of Pregnancy: Recent Advances in Hypertension. Hypertension 2021, 78, 927-935. [CrossRef] [PubMed] 